The stability of tide gauges in the South Pacific determined from multi-epoch geodetic levelling, 1992 to 2010

Manoj Nilesh Deo ${ }^{1}$, Ramesh Govind ${ }^{2}$, Ahmed El-Mowafy ${ }^{3}$

${ }^{1}$ PhD Candidate, Department of Spatial Science, Curtin University, GPO Box U1987 Perth, Western Australia 6845

${ }^{2}$ Minerals and Natural Hazards Division, Geoscience Australia, GPO Box 378,

Canberra, ACT 2601, Australia

${ }^{3}$ Senior Lecturer, Curtin University, GPO Box U1987 Perth, Western Australia 6845

Phone: +61262932420

Facsimile: +61262932420

Email: Manoj.Deo01@gmail.com 


\section{The stability of tide gauges in the South Pacific determined from multi-epoch geodetic levelling, 1992 to 2010}

Tide gauge data forms the basis for determining global or local sea level rise with respect to a global geocentric reference frame. Data from repeated precise levelling connections between the tide gauges and a series of coastal and inland benchmarks, including a Continuous GPS (CGPS) benchmarks, is used to determine the stability of tide gauges at 12 locations in the South Pacific. The method for determining this stability is based on using a constant velocity model which minimises the net movement amongst a set of datum benchmarks surveyed since the installation of the tide gauges. Tide gauges were found to be sinking, relative to the CGPS benchmark, in Pohnpei (FSM), Samoa, Vanuatu, Tonga, Nauru, Tuvalu, Fiji and Cook Islands (Is); listed in order of their sinking rate. A maximum of $-1.01 \pm 0.63 \mathrm{~mm} / \mathrm{yr}$ is computed at Pohnpei (FSM) and the minimum at Cook Is was statistically insignificant. The tide gauge levels were rising, relative to the CGPS benchmark in Solomon Is, Manus Is (PNG), Kiribati and Marshall Is, with a maximum of $3.12 \pm 0.49 \mathrm{~mm} / \mathrm{yr}$ at Solomon Is and a minimum at Marshall Is, which was statistically insignificant. However, these estimates are unreliable for the Solomon Is and Marshall Is, which have recently established CGPS benchmarks and have been surveyed less than 3 times. In Tonga and Cook Is, the tide gauges were found to be disturbed or affected by survey errors whereas the Vanuatu results were affected by earthquakes. It was also found that the constant velocity model did not fit the observations at the tide gauges in Tonga, Cook Is, Fiji, Marshall Is and Vanuatu, which had large variations in their velocities. This is an indicator of the high frequency (short period) motion of the tide gauge structure, which cannot be measured by the levelling method since they have a higher frequency than the time interval between levelling surveys.

Keywords: precise levelling; vertical velocity; inner constraint adjustment; deformation monitoring; sea level monitoring

\section{Introduction}

The South Pacific Regional GPS Network (SPRGN) consists of Continuous Global Position System (CGPS) stations located in 12 Pacific Island countries. The SPRGN was established under the South Pacific Sea Level and Climate Monitoring Project (SPSLCMP). This project was funded by AusAID and developed in 1991 as an Australian Government response to concerns raised by Pacific Island countries over the impact of global warming on climate change and sea level rising in the Pacific region (Bureau of Meteorology, 2007). The project also supports the operation of SEAFRAME tide gauges co-located with the CGPS stations within proximity of a few kilometres. The locations of these sensors are shown in Figure 1. The installation of the CGPS stations has commenced in 2001 during the five-year third phase of the project. The installation dates of the tide gauge sensors and the CGPS stations are summarised in Table 1. 


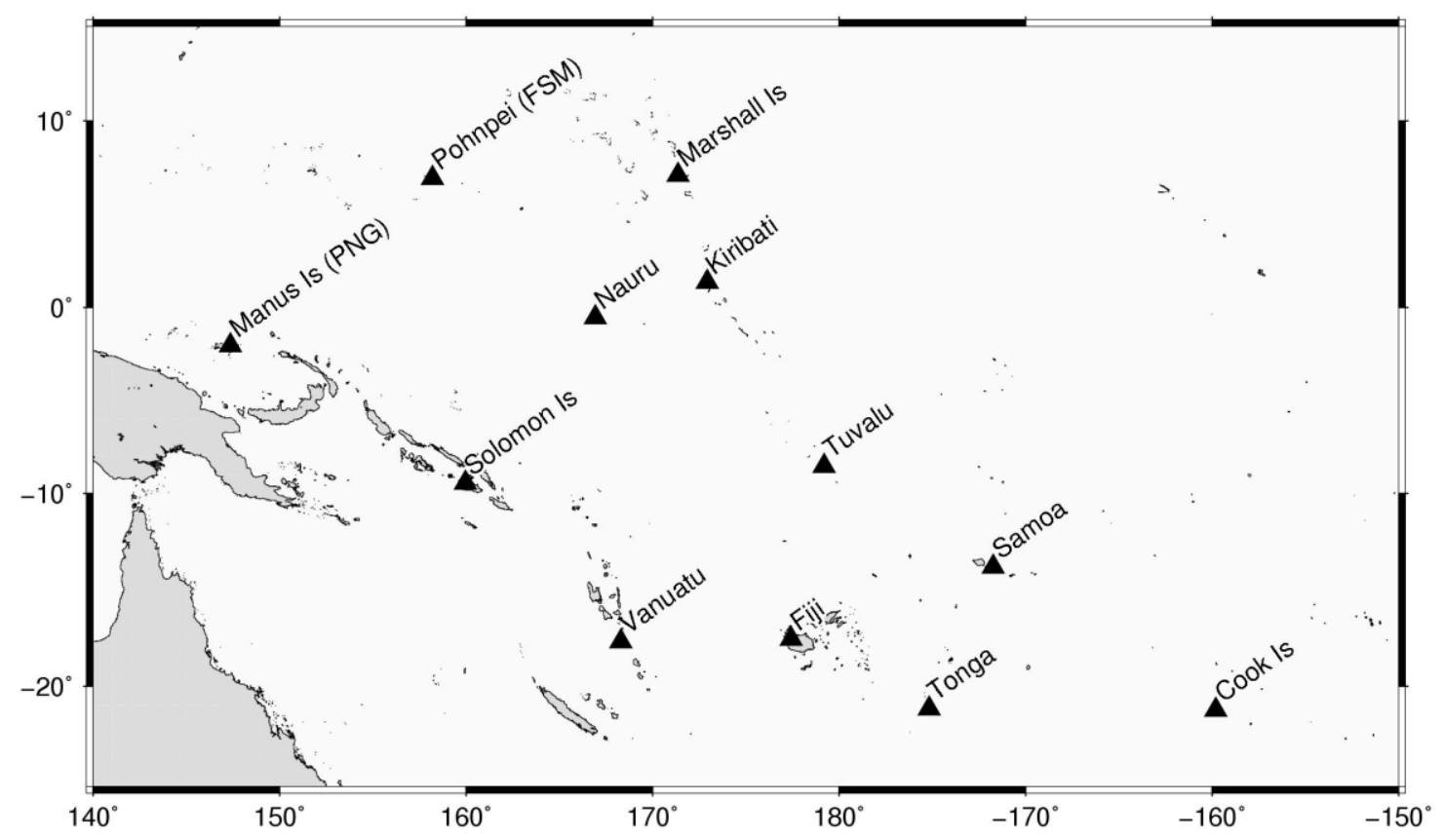

Figure 1: The South Pacific Regional GPS Network

Table 1: Installation dates for the tide gauge sensors and CGPS stations in the South Pacific.

\begin{tabular}{|l|l|l|l|}
\hline Location & $\begin{array}{l}\text { Tide Gauge Sensor } \\
\text { installation }\end{array}$ & $\begin{array}{l}\text { CGPS station } \\
\text { installation }\end{array}$ & $\begin{array}{l}\text { Levelling } \\
\text { distance } \\
\text { between the tide } \\
\text { gauge and GPS } \\
\text { (km) }\end{array}$ \\
\hline Cook Is & Feb 1993 & Sep 2001 & 1.94 \\
\hline Fiji & Oct 1992 & Nov 2001 & 1.92 \\
\hline Kiribati & Dec 1992 & Aug 2002 & 2.27 \\
\hline Manus Is (PNG) & Sep 1994 & May 2002 & 1.09 \\
\hline Marshall Is & May 1993 & May 2007 & 2.08 \\
\hline Nauru & Jul 1993 & July 2003 & 3.81 \\
\hline Pohnpei (FSM) & Dec 2001 & May 2003 & 3.47 \\
\hline Samoa & Feb 1993 & July 2001 & 5.04 \\
\hline Solomon Is & Jul 1994 & Jun 2008 & 1.31 \\
\hline Tonga & Jan 1993 & Feb 2002 & 1.17 \\
\hline Tuvalu & Mar 1993 & Dec 2001 & 3.47 \\
\hline Vanuatu & Jan 1993 & Sep 2002 & 3.43 \\
\hline
\end{tabular}

The absolute vertical velocity of the CGPS stations is determined from combining long-term GPS solutions in relative positioning with $\mathrm{mm}$ accuracy, in a globally consistent geocentric terrestrial reference frame such as the International Terrestrial Reference Frame (ITRF) available, for example, from the ITRF2008 solution (Altamimi et al., 2011). Typically, velocities are determined with $\mathrm{mm}$ accuracy from GPS solutions when presented in ITRF when observations are collected over a long 
period of several hours (see for instance, Donnelly 2012). In general, the CGPS monument consists of a $1.5 \mathrm{~m}$ concrete pillar with a solid concrete foundation on geologically stable ground, measuring $2 \mathrm{~m} \times 2 \mathrm{~m}$ with a depth of up to $4 \mathrm{~m}$. However, the tide gauges are usually located on wharves, which are structurally unstable and subject to gradual movements. Thus, continuous monitoring of the vertical movement of the tide gauges is required relative to the CGPS stations, at an accuracy higher than the velocities of the CGPS stations or tide gauge estimates of relative seal level rise. The Tide Gauge Benchmark Monitoring Pilot Project (TIGA-PP) has identified the importance of high quality ties between the tide gauge and CGPS stations (Blewitt et al., 2006). For periods earlier than the installation of the CGPS, the vertical monitoringof tide gauges was undertaken relative to an array of deep driven benchmarks (BM). These BMs consist of high quality durable steel, driven several metres into the ground until it reaches bedrock or other stable material. The vertical movement of the tide gauge is monitored by precise geodetic levelling (1993 to 2006) and thereafter by EDM trigonometric height traversing using Total stations (Rueger \& Brunner, 1981). The levelling surveys are repeated at approximately 1.5 year intervals, and each survey takes about a week to complete. A typical survey involves forward and backward level runs between BMs located along the levelling route from the tide gauge to the CGPS BM.

Several studies have been done to determine velocities and uplift rates of BMs from repeated levelling (Maniken and Saaranen, 1998; Makinen et al., 2003; Schlatter et al., 2005; Lenotre et al., 1999; Verdonck, 2006; Kimata et al., 2004; Murray and Wooller, 2002). Anastasio et al. (2006) estimated vertical movements of BMs in a complex geodynamic location in Italy. In these approaches, the height changes were referenced to a single BM, which was considered to be stable; and the movement of all other marks is determined relative to this BM. The results can be significantly corrupted if the fundamental BM moves between successive levelling surveys.

A recent global estimate for sea level rise in the past century has been estimated as $1.7 \mathrm{~mm} \pm 0.2 \mathrm{~mm} / \mathrm{yr}$ (Church and White, 2011), which has a similar rate to previous values estimated by Tushingham and Peltier (1991) and Douglas (1997). The uncertainty in the vertical rate of the tide gauge should be one order of magnitude less than the uncertainty of the sea level rise estimates so that the sea level rise estimates can be correctly interpreted or understood.

This research avoids referencing the movement of all points to a single BM. A least squares with an inner constrain approach has been used for estimating the vertical velocities, their uncertainties and the initial heights of BMs over two decades of repeated levelling data. The method also accounts for local geophysical effects such as earthquakes.

The structure of the paper is as follows. Section 2 describes the method of adjustment employed in this study, which minimises the nett motion of a subset of datum points. Section 3 describes the raw data under consideration and its reduction procedures. Results are presented in Sections 4, with discussions and conclusions given in Section 5 and 6, respectively. 


\section{Methodology}

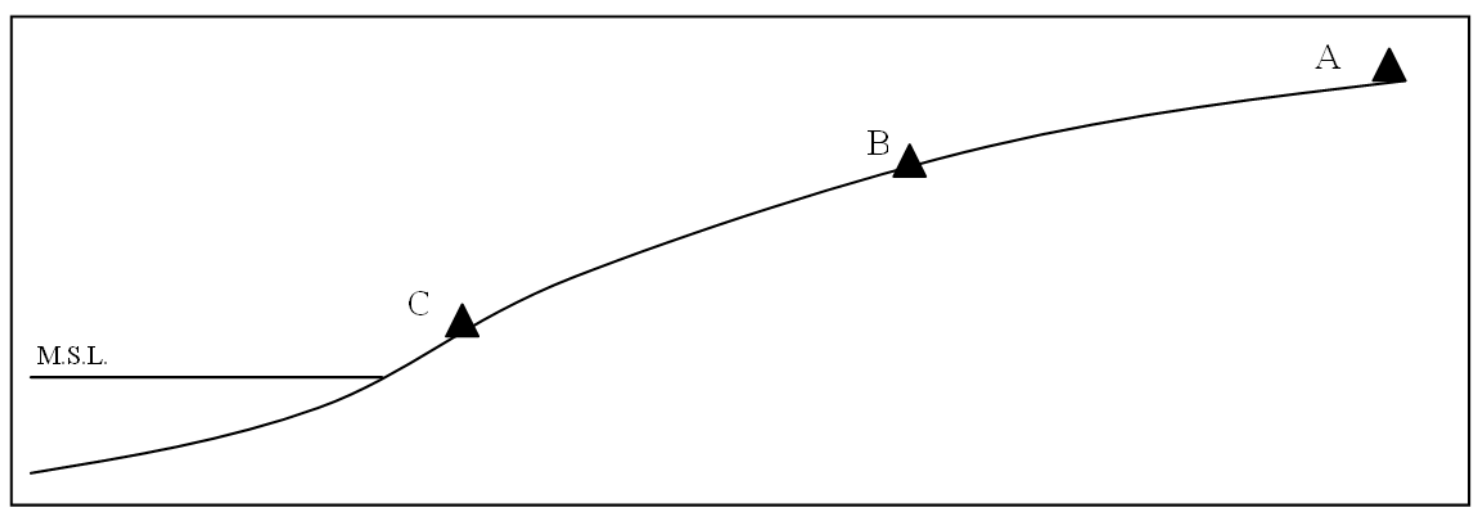

Figure 2: Simple levelling array

Consider an array of coastal and inland deep driven BMs, A, B and C, as illustrated in Figure 2 and assume that each $\mathrm{BM}$ is deforming with a constant vertical velocity. The observation equations for the measured relative height difference, $\Delta H_{B A}, \Delta H_{C B}$ at the initial epoch, $t_{0}$, and subsequent epochs, $t_{i}$, are expressed in a relative monitoring, where all points are considered as unstable and subject to motion as follows (Leal, 1989)

$$
\begin{aligned}
& H_{A}\left(t_{0}\right)-H_{B}\left(t_{0}\right)+\left(t_{i}-t_{0}\right)\left(\dot{H}_{A}-\dot{H}_{B}\right)=\Delta H_{B A}\left(t_{i}\right)+v_{B A}\left(t_{i}\right) \\
& H_{B}\left(t_{0}\right)-H_{C}\left(t_{0}\right)+\left(t_{i}-t_{0}\right)\left(\dot{H}_{B}-\dot{H}_{C}\right)=\Delta H_{C B}\left(t_{i}\right)+v_{C B}\left(t_{i}\right)
\end{aligned}
$$

where $\dot{H}_{A}, \dot{H}_{B}$ and $\dot{H}_{C}$ are the velocities of points $\mathrm{A}, \mathrm{B}$ and $\mathrm{C}$ and $H_{A}\left(t_{0}\right), H_{B}\left(t_{0}\right)$ and $H_{C}\left(t_{0}\right)$ are their initial heights; $\Delta H_{B A}$ and $\Delta H_{C B}$ are the relative heights between the points A-B and B-C, $v_{B A}$ and $v_{C B}$ are small residuals in the observation model, which are assumed Gaussian white noise. From Equations (1-2), if we have $n$ number of points, we will have ( $n-1)$ observations (differential heights) and $2 n$ unknowns (velocity and initial height for each point). A rank deficiency would result in the design matrix for a least squares solution for the problem at hand unless there are at least $[2 n /(n-1)]$ epochs of survey data. For the given example, at least three epochs of data are needed to remove rank deficiency. Instead of holding the height of one bench mark fixed, as is the case in the traditional approach, an inner constraint is introduced to facilitate direct comparison of multi-epoch data on a consistent datum. The constraint imposed is that the mean height of a set of datum points, as determined in the initial survey, remains constant for all subsequent epochs, such that for the given example:

$$
H_{A}\left(t_{i}\right)+H_{B}\left(t_{i}\right)+H_{C}\left(t_{i}\right)=H_{A}\left(t_{0}\right)+H_{B}\left(t_{0}\right)+H_{C}\left(t_{0}\right)
$$

and considering

$$
H_{A}\left(t_{i}\right)=H_{A}\left(t_{0}\right)+\left(t_{i}-t_{0}\right) \dot{H}_{A}
$$




$$
H_{B}\left(t_{i}\right)=H_{A}\left(t_{i}\right)-\Delta H_{B A}\left(t_{i}\right)
$$

and

$$
H_{C}\left(t_{i}\right)=H_{B}\left(t_{i}\right)-\Delta H_{C B}\left(t_{i}\right)=H_{A}\left(t_{i}\right)-\Delta H_{B A}\left(t_{i}\right)-\Delta H_{C B}\left(t_{i}\right)
$$

Substituting Equations (5) and (6) into (3) results in the following condition equation for each epoch of survey

$$
2 H_{A}\left(t_{0}\right)-2 \Delta H_{B A}\left(t_{i}\right)-\Delta H_{C B}\left(t_{i}\right)=H_{B}\left(t_{0}\right)+H_{C}\left(t_{0}\right)-3\left(t_{i}-t_{0}\right) \dot{H}_{A}
$$

. In order to introduce a height datum, the height of one of the datum points, e.g. $H_{A}\left(t_{0}\right)$, is adopted as an approximate value, thus is known. For each epoch of survey, there are $n-1$ observation equations, one condition equation (Equation 7) and 2n-1 unknowns (since $H_{A}\left(t_{0}\right)$ is known), thus a solution is possible with just two epochs of data. The parameters to be solved using least squares will comprise the initial heights of the BMs and their point velocities, given as:

$$
\mathbf{x}=\left[\begin{array}{lllll}
H_{B}\left(t_{0}\right) & H_{C}\left(t_{0}\right) & \dot{H}_{A} & \dot{H}_{B} & \dot{H}_{C}
\end{array}\right]^{T}
$$

For the given example, with two epochs of survey $\left(t_{1}\right.$ and $\left.t_{2}\right)$, there are six equations and five unknowns. The combined observation and condition equations read:

$$
\left[\begin{array}{c}
\Delta H_{B A}\left(t_{1}\right)-H_{A}\left(t_{0}\right) \\
\Delta H_{C B}\left(t_{1}\right) \\
2 H_{A}\left(t_{0}\right)-2 \Delta H_{B A}\left(t_{1}\right)-\Delta H_{C B}\left(t_{1}\right) \\
\Delta H_{B A}\left(t_{2}\right)-H_{A}\left(t_{0}\right) \\
\Delta H_{C B}\left(t_{2}\right) \\
2 H_{A}\left(t_{0}\right)-2 \Delta H_{B A}\left(t_{2}\right)-\Delta H_{C B}\left(t_{2}\right)
\end{array}\right]=\left[\begin{array}{ccccc}
-1 & 0 & \left(t_{1}-t_{0}\right) & -\left(t_{1}-t_{0}\right) & 0 \\
1 & -1 & 0 & \left(t_{1}-t_{0}\right) & -\left(t_{1}-t_{0}\right) \\
1 & 1 & -3\left(t_{1}-t_{0}\right) & 0 & 0 \\
-1 & 0 & \left(t_{2}-t_{0}\right) & -\left(t_{2}-t_{0}\right) & 0 \\
1 & -1 & 0 & \left(t_{2}-t_{0}\right)-\left(t_{2}-t_{0}\right) \\
1 & 1 & -3\left(t_{2}-t_{0}\right) & 0 & 0
\end{array}\right]\left[\begin{array}{c}
H_{B}\left(t_{0}\right) \\
H_{C}\left(t_{0}\right) \\
\dot{H}_{A} \\
\dot{H}_{B} \\
\dot{H}_{C}
\end{array}\right]
$$

The variances of these parameters, given in this paper, are adopted from the diagonal of the inverse normal matrix in the least squares solution. Initially, the datum points consist of high quality deep driven bench marks (i.e. structurally stable) which have been surveyed since the first epoch, $t_{0}$. The choice of which BM to take its initial height for this purpose is arbitrary and will not affect the vertical velocities determined. The estimated heights can be shifted to another datum value, if required. In addition, during successive levelling, some datum points may be destroyed or found to deform significantly relative to other datum points. This requires their elimination from the datum list. However, it must be ensured that the condition defined by the inner constraints can be re-established in all subsequent epochs in order to directly compare results of different epochs. Therefore, the datum points considered for such comparison must be the same in the initial epoch and during subsequent epochs. 


\section{Modelling effects of earthquakes and other discontinuities}

If any of the BMs are found to be disturbed by earthquakes, physical impacts or localised deformations, a height discontinuity is introduced. It is assumed that the velocity remains the same before and after the event. For example, if a displacement occurred at a non-datum BM (X) along the levelling run, which lies between the datum points $\mathrm{B}$ and $\mathrm{C}$, the observation equation becomes

$$
\Delta H_{X B}\left(t_{i}\right)+v_{X B}\left(t_{i}\right)=H_{B}\left(t_{0}\right)-H_{X}\left(t_{0}\right)+\mathbf{h}_{\mathbf{e}}+\left(t_{i}-t_{0}\right)\left(\dot{H}_{B}-\dot{H}_{X}\right)
$$

Where $\mathbf{h}_{\mathbf{e}}$ is the height displacement vector between BMs B and $\mathrm{X}$. The displacement vector is introduced on the date of the event and remains in the observation equations for all subsequent epochs. A similar equation can be formulated for the observation from $\mathrm{X}$ to $\mathrm{C}$, by reversing the sign of the displacement vector. Equation (3) remains unchanged since the displacement does not affect the inner constraint condition, i.e. the mean height of the datum points remains unchanged.

\section{Description of the Data Used in this Study}

The data used in this study were from levelling surveys conducted in 12 Pacific Island countries during the period 1992 to 2010. Details of the survey epochs and incountry surveys are given in Table 2. The fundamental BMs, which were held fixed in previous survey reports, e.g. from Geoscience Australia (2007), are shown in the last column of the table in bold font. In total, data from 42 points were included in datum computation. Precise geodetic levelling was the method of survey between 1992 and 2005, and EDM trigonometric height traversing was used thereafter. A comparison between height results computed from the two methods during the period 2004-2006 was undertaken in each country (except the Solomon Islands). The epochs for which the tide gauges were connected to the CGPS BMs are shown in bold font in the second column of Table 2. The precise levelling was done using a first order automatic level (Wild NA 3003) with $2 \mathrm{~m}$ invar staves. The manufacturer specified precision for this equipment is $0.4 \mathrm{~mm} / \mathrm{km}$ for a backward and forward run. Considering a maximum levelling distance of $5 \mathrm{~km}$ at Samoa, the expected levelling error would be $2 \mathrm{~mm}$. This makes it possible to detect the stability of the tide gauge at 1.5 year intervals to within the precision of current sea level rise estimates of $1.7 \mathrm{~mm} \pm 0.2 \mathrm{~mm} / \mathrm{yr}$.

The instruments used for EDM trigonometric height determination were Leica total stations (TCA1800 and TCA2003) with high quality prisms (GPH1A). The manufacturer specified angular precision of these equipment are 1 " and 0.5 " for TCA1800 and TCA2003, respectively, and $1 \mathrm{~mm}+1 \mathrm{ppm}$ for distance measurements. The backsight and foresight distances are kept equal to within $0.5 \mathrm{~m}$. The standard deviation in the height difference measured between two points, defined as $s_{\Delta H}$, is given as (Ceylan and Baykal, 2006)

$$
s_{\Delta H}=\sqrt{2 \cos ^{2} Z \cdot \sigma_{D}^{2}+2 \sin ^{2} Z \cdot \sigma_{Z}^{2}+\frac{D^{4}}{4 R^{2}} \sigma_{\Delta k}^{2}}
$$

where $Z$ is the zenith angle, $D$ is the sight distance, $R$ is the mean radius of the Earth $(6371 \mathrm{~km}), \sigma_{D}$ and $\sigma_{Z}$ are the standard deviations of the distance and zenith angle, respectively and $\sigma_{\Delta k}$ is the uncertainty in the difference of the coefficient of refraction 
between the two points. A sight distance of $50 \mathrm{~m}$ and a slope of 5 degrees are typical in the South Pacific environment. Taking the uncertainty in the coefficient of refraction as 0.05 for the forward and backward run (ibid.), the uncertainty in height difference between two consecutive points at $100 \mathrm{~m}$ apart is evaluated as $0.12 \mathrm{~mm}$. Assuming that all instrument setups were independent of each other and applying the law of propagation of errors, the total uncertainty in $5 \mathrm{~km}$ of total levelling distance would be $\pm 0.86 \mathrm{~mm}$. Thus tide gauge BM stability is also possible using trigonometric height traversing with a high precision total station.

Table 2: Details of the levelling surveys in each country. The epochs for which the tide gauges were connected to the CGPS BMs are shown in bold font in the second column. The fundamental BMs which were previously held fixed are shown in bold font in the last column.

\begin{tabular}{|c|c|c|}
\hline Country & Epochs of survey & Datum points \\
\hline Cook Is & $\begin{array}{l}\text { Feb 1993, Dec 1994, June 1996, June 1998, } \\
\text { Nov 1999, Jun 2001, Nov 2002, Aug 2004 } \\
\text { (Comparison), Jan 2007, Jun 2008, Dec } 2009\end{array}$ & $\begin{array}{l}\text { (BM26, } \\
\text { BM27, BM28) }\end{array}$ \\
\hline Fiji & $\begin{array}{l}\text { Oct 1992, Aug 1994, Nov 1995, Jun 1997, Nov } \\
\text { 1998, Dec 2000, Mar 2002, May 2003, May } \\
\text { 2005 (Comparison), Feb 2007, Sep 2008, Feb } \\
2010\end{array}$ & $\begin{array}{l}3 \text { (BM3243, } \\
\mathrm{BM} 3244-5)\end{array}$ \\
\hline Kiribati & $\begin{array}{l}\text { Dec 1992, Mar 1994, Mar 1995, Sep 1996, Dec } \\
\text { 1997, Jun 1999, Aug 2000, June 2002, May } \\
\text { 2004, Mar 2006 (Comparison), Nov 2007, } \\
\text { Mar 2009, Sep } 2010\end{array}$ & $\begin{array}{l}3 \text { (KIR1, KIR2- } \\
\text { 3) }\end{array}$ \\
\hline Manus Is (PNG) & $\begin{array}{l}\text { Aug 1994, Mar 1996, Sep 1997, Mar 1999, Nov } \\
\text { 2000, May 2002, Sep 2003, Jan } 2006 \\
\text { (Comparison), Aug 2007, Jun 2009, Dec } \mathbf{2 0 1 0}\end{array}$ & $\begin{array}{l}2 \text { (PNG1, } \\
\text { PNG3) }\end{array}$ \\
\hline Marshall Is & $\begin{array}{l}\text { May 1993, Jun 1994, July 1995, Dec 1996, Aug } \\
\text { 1998, Apr 2000, Sep 2001, Feb 2003, May } \\
2006 \text { (Comparison), Oct 2007, Apr 2009, Oct } \\
2010\end{array}$ & $\begin{array}{l}4 \text { (MAR3, } \\
\text { MAR50-52) }\end{array}$ \\
\hline Nauru & $\begin{array}{l}\text { Jul 1993, Mar 1994, Mar 1995, Sep 1996, Dec } \\
\text { 1997, Jun 1999, Aug 2000, Jun 2002, Nov } \\
\text { 2003, Oct 2005 (Comparison), Jun 2007, Feb } \\
\text { 2009, Jul } 2010\end{array}$ & $\begin{array}{l}3 \text { (NAU1, } \\
\text { NAU2, } \\
\text { NAU16) }\end{array}$ \\
\hline Pohnpei (FSM) & $\begin{array}{l}\text { Dec 2001, Mar 2003, June } 2006 \\
\text { (Comparison), Mar 2008, Aug } 2009\end{array}$ & $\begin{array}{l}5 \text { (FSM1, } \\
\text { FSM2-5) }\end{array}$ \\
\hline Samoa & $\begin{array}{l}\text { Oct 1993, Nov 1994, Jun 1996, Aug 1998, Nov } \\
\text { 1999, Jun 2001, Dec 2002, Sep 2004, Oct } 2006 \\
\text { (comparison), May 2008, May 2010 }\end{array}$ & $\begin{array}{l}7 \text { (BM201, } \\
\text { BM210, } \\
\text { BM212-5, } \\
\text { SAMOBM) }\end{array}$ \\
\hline Solomon Is & $\begin{array}{l}\text { Aug 1994, Feb 1996, Aug 1997, Mar 1999, } \\
\text { Aug 2007, May 2009, Nov } 2010\end{array}$ & $\begin{array}{l}3 \text { (FBM4, } \\
\text { FBM3, FBM1) }\end{array}$ \\
\hline Tonga & $\begin{array}{l}\text { Jan 1993, Sep 1994, Nov 1995, Jun 1997, Nov } \\
\text { 1998, May 2000, Feb 2002, Jun 2003, June } \\
2005 \text { (Comparison), Mar 2007, Oct 2008, Apr } \\
2010\end{array}$ & $\begin{array}{l}\text { (TON1, } \\
\text { TON2-3) }\end{array}$ \\
\hline Tuvalu & Mar 1993, Jun 1994, Jun 1995, Dec 1996, Jul & 3 (BM22, \\
\hline
\end{tabular}




\begin{tabular}{|l|l|l|}
\hline & $\begin{array}{l}\text { 1998, Mar 2000, Aug 2001, May 2003, Sep } \\
\text { 2005 (Comparison), Mar 2007, Jan 2009, } \\
\text { Aug 2010 }\end{array}$ & \\
\hline Vanuatu & $\begin{array}{l}\text { Jan 1993, Jan 1994, Mar 1995, Feb 1997, Mar } \\
\text { 1998, Aug 1999, Mar 2001, Sep 2002, May } \\
\text { 2004, Sep 2006 (Comparison), Apr 2008, Sep } \\
\text { 2009 }\end{array}$ & VAN100-101) \\
\end{tabular}

A typical levelling survey consists of a levelling route commencing at the tide gauge point and terminating at the CGPS BM. The distance between these two points is given in Table 1. A series of deep driven (stable) BMs were placed along the route, which were levelled to during traversing. Generally, it is aimed to have one deep driven BM for every kilometre of levelling. The levelling run is split into a backward and forward run between two consecutive deep driven bench marks, while keeping the closure errors to within the first order levelling standards (Geoscience Australia, 2007). Initially, the deep driven BMs that have been surveyed since the initial epoch were adopted as datum points. Since the duration of each survey is relatively short (approximately 1 week), it is assumed that no deformation occurred during this period and the epoch of survey is adopted as the middle of this period.

The precise levelling observations were available to our study from the National Tidal Centre, Australian Bureau of Meteorology. The trigonometric height traversing observations were available from the National Geospatial Reference System (NGRS) Project records, Geoscience Australia. The observations used in this study are the measured height differences between successive BMs measured at multiple epochs. These height differences have been corrected for closure errors.

\section{EDM Trigonometric Height Traversing}

Trigonometric height traversing was performed through the use of the leap-frog approach. The distance measurements were corrected for temperature, pressure and relative humidity effects. No geometric corrections were applied to the distances to correct for projection effects and nor was any correction applied for refraction. Refraction errors were almost eliminated using a standard field procedure of keeping the back and forward sight distances between the total and the target stations equal. This was ensured by measuring the sight distances prior to setting up the instrument using a box tape, with an accuracy of $0.1 \mathrm{~m}$. Residual refraction errors which may remain are highly random and dominated by the gradient of the terrain as well as distance to the forward and backward targets (Holdahl, 1979). They are practically eliminated when keeping the sight distances below $100 \mathrm{~m}$ (Kharangani, 1987). Since the average gradient of the terrain in the study areas was quite low (below 5 degrees) and the sight distances to the forward and backward targets were typically less than $50 \mathrm{~m}$, refraction errors were not corrected any further.

\section{Observation weighting}

The observations were weighted at first order levelling precision, with a standard deviation of $1 \mathrm{~mm}$ per $\sqrt{k}$, where $k$ is the levelled distance in $\mathrm{km}$. This level of accuracy was routinely achieved by both levelling methods, as indicated by the survey closures between the forward and backward level runs. If the survey misclose exceeds 
this tolerance, the levelling is repeated by the survey party.

\section{Results}

Table 3 shows the initial heights and vertical velocity estimates with their standard deviations computed from the least-squares adjustment using the presented method for the fundamental datum BMs (which were held fixed in previous surveys). The CGPS $\mathrm{BM}$ and tide gauges for all locations are also given in the table. The standard deviations were obtained from the least squares variance matrix, where they were not statistically significant in some cases. Table 3 also gives the overall Root-Mean-Square (RMS) of residuals for each country's adjustment. The fundamental BMs in Cook Is, Fiji, Samoa and Vanuatu exhibit significant velocities after applying the inner constraint adjustment. They were erroneously held fixed with zero velocity in previous surveys.

Table 3: Initial heights and vertical velocity estimates, with their standard deviations, of fundamental datum BMs, CGPS BMs and the tide gauges in the Pacific Islands

\begin{tabular}{|c|c|c|c|c|c|c|c|}
\hline Country & $\begin{array}{l}\text { Residual } \\
\text { RMS } \\
(\mathbf{m m})\end{array}$ & BM & $\begin{array}{l}\mathbf{H}\left(\mathbf{t}_{\mathbf{0}}\right) \\
(\mathbf{m})\end{array}$ & $\begin{array}{l}\sigma \mathbf{H}\left(\mathbf{t}_{\mathbf{0}}\right) \\
(\mathbf{m m})\end{array}$ & $\begin{array}{l}\text { Velocity } \\
(\mathrm{mm} / \mathrm{yr})\end{array}$ & $\begin{array}{l}\sigma \text { Velocity } \\
(\mathrm{mm} / \mathrm{yr})\end{array}$ & Description \\
\hline \multirow[t]{3}{*}{ Cook Is } & \multirow[t]{3}{*}{0.83} & BM27 & 4.7407 & - & 0.32 & 0.11 & Datum BM \\
\hline & & COO56 & 2.6876 & 2.47 & 0.06 & 0.24 & Tide gauge \\
\hline & & CGPS BM & 3.2576 & 9.84 & 0.09 & 0.77 & \\
\hline \multirow[t]{3}{*}{ Fiji } & \multirow[t]{3}{*}{0.95} & BM3243 & 3.1285 & - & -0.45 & 0.08 & Datum BM \\
\hline & & FIJ 13 & 4.4316 & 1.11 & 0.14 & 0.13 & Tide gauge \\
\hline & & CGPS BM & 31.3285 & 3.74 & 0.19 & 0.28 & \\
\hline \multirow[t]{3}{*}{ Kiribati } & \multirow[t]{3}{*}{0.52} & KIR1 & 3.5334 & - & 0.03 & 0.08 & Datum BM \\
\hline & & KIR13 & 4.6319 & 1.88 & 0.05 & 0.20 & Tide gauge \\
\hline & & CGPS BM & 4.4127 & 2.07 & 0.04 & 0.18 & \\
\hline \multirow{3}{*}{$\begin{array}{l}\text { Manus } \\
\text { Is } \\
\text { (PNG) }\end{array}$} & \multirow[t]{3}{*}{0.66} & PNG1 & 2.2988 & - & -0.06 & 0.04 & Datum BM \\
\hline & & PNG14 & 4.5799 & 0.46 & -0.08 & 0.06 & Tide gauge \\
\hline & & CGPS BM & 37.6890 & 1.82 & -0.20 & 0.15 & \\
\hline \multirow{3}{*}{$\begin{array}{l}\text { Marshall } \\
\text { Is }\end{array}$} & \multirow[t]{3}{*}{1.33} & MAR3 & 1.6083 & - & -0.06 & 0.50 & Datum BM \\
\hline & & MAR14 & 2.7920 & 3.15 & 0.02 & 0.75 & Tide gauge \\
\hline & & CGPS BM & 3.1418 & 4.86 & 0.01 & 0.51 & \\
\hline \multirow[t]{3}{*}{ Nauru } & \multirow[t]{3}{*}{0.48} & NAU1 & 7.2930 & - & -0.09 & 0.10 & Datum BM \\
\hline & & NAU15 & 6.0033 & 0.78 & 0.14 & 0.13 & Tide gauge \\
\hline & & CGPS BM & 5.2538 & 16.72 & 0.47 & 1.26 & \\
\hline \multirow{3}{*}{$\begin{array}{l}\text { Pohnpei } \\
\text { (FSM) }\end{array}$} & \multirow[t]{3}{*}{0.85} & FSM1 & 2.4382 & - & -0.07 & 0.13 & Datum BM \\
\hline & & FSM55 & 4.0330 & 0.64 & -0.30 & 0.19 & Tide gauge \\
\hline & & CGPS BM & 38.0036 & 2.96 & 0.71 & 0.60 & \\
\hline
\end{tabular}




\begin{tabular}{|c|c|c|c|c|c|c|c|}
\hline \multirow{3}{*}{ Samoa } & \multirow{3}{*}{0.43} & BM201 & 1.3292 & - & -0.44 & 0.15 & Datum BM \\
\hline & & SAM17 & 4.1634 & 0.90 & -0.72 & 0.30 & Tide gauge \\
\hline & & CGPS BM & 38.1882 & 1.41 & 0.22 & 0.38 & Datum BM \\
\hline \multirow{3}{*}{$\begin{array}{l}\text { Solomon } \\
\text { Is }\end{array}$} & \multirow[t]{3}{*}{0.73} & FBM4 & 3.6197 & - & -0.07 & 0.03 & Datum BM \\
\hline & & SOL18 & 3.5756 & 0.55 & -0.36 & 0.06 & Tide gauge \\
\hline & & CGPS BM & 54.3598 & 7.28 & -3.48 & 0.49 & \\
\hline \multirow[t]{3}{*}{ Tonga } & \multirow[t]{3}{*}{1.05} & TON1 & 1.1186 & - & -0.08 & 0.19 & Datum BM \\
\hline & & TON16 & 3.8944 & 4.24 & -0.38 & 0.46 & Tide gauge \\
\hline & & CGPS BM & 1.9816 & 15.92 & -0.01 & 1.21 & \\
\hline \multirow[t]{3}{*}{ Tuvalu } & \multirow[t]{3}{*}{0.55} & BM22 & 3.2254 & - & -0.01 & 0.05 & Datum BM \\
\hline & & TUV20 & 4.4608 & 0.96 & -0.11 & 0.11 & Tide gauge \\
\hline & & CGPS BM & 2.7421 & 6.70 & -0.01 & 0.49 & \\
\hline \multirow[t]{3}{*}{ Vanuatu } & \multirow[t]{3}{*}{0.62} & VAN3 & 23.5463 & - & -0.17 & 0.24 & Datum BM \\
\hline & & VAN16 & 5.0104 & 3.09 & -0.44 & 0.98 & Tide gauge \\
\hline & & CGPS BM & 32.9070 & 3.42 & 0.40 & 0.56 & \\
\hline
\end{tabular}

To transform the previously determined heights onto a height datum with inner constraint applied, the velocity of the fundamental BM determined from the inner constraint adjustment was applied to the heights from previous surveys, where they were held fixed. The transformed heights are computed as $H_{B M}+\left(t_{i}-t_{0}\right) \dot{H}_{B M}$, where $H_{B M}$ is the height of a BM from previous surveys and $H_{B M}$ is its velocity. Table 4 shows the RMS of the deviations of the transformed height from the fixed heights adjusted by the constant velocity vector for the tide gauges and CGPS BMs in each country. Figure 3 shows this effect for the tide gauge in Fiji, as an example.

The nett velocity of the tide gauge relative to the GPS BM and its standard deviation is given in Table 5 for all the 12 tide gauges. This is calculated by subtracting the velocity of the CGPS BM from the tide gauge velocity vector. Its standard deviation is determined using the law of propagation of errors. Another item of interest is the raw offsets between the CGPS BM and the tide gauge point compared to the same offsets after applying the inner constraint adjustment. The raw offsets are obtained by simply differencing the tide gauge heights $\left(H_{T G}\right)$ from the CGPS BM height $\left(H_{B M}\right)$ at each epoch $H_{T G}-H_{B M}$, whereas the offset after applying the adjustment is affected by their relative velocities. The offsets were computed as $\left[H_{T G}\left(t_{0}\right)-H_{B M}\left(t_{0}\right)\right]+\left(t_{i}-t_{0}\right)\left(\dot{H}_{T G}-\dot{H}_{B M}\right)$. These offsets are given in Appendix A. Figure 4 shows the raw offset between the heights of CGPS BMs and the tide gauges for surveys after installation of the CGPS and the modelled offsets prior to this. Solomon Is has been excluded since it had high residuals due to insufficient levelling connections after establishment of the CGPS. A downward trend signifies a sinking tide gauge and the linear component prior to CGPS installation is estimated from the inner constraint adjustment. Note the high variations in Vanuatu due to earthquake 
disturbances, Cook Islands due to survey errors and Tonga due to disturbance to the tide gauge.

Table 4: RMS of deviations from constant velocity model

\begin{tabular}{|l|l|l|}
\hline Country & $\begin{array}{l}\text { RMS }(\mathbf{m m}) \text { of } \\
\text { transformed height }- \\
\left(\mathbf{H}_{\mathbf{0}}+\dot{\mathbf{H}}\right) \text { at the tide gauge }\end{array}$ & $\begin{array}{l}\text { RMS }(\mathbf{m m}) \text { of } \\
\text { transformed height }- \\
\left(\mathbf{H}_{\mathbf{0}}+\dot{\mathbf{H}}\right) \text { at the CGPS BMs }\end{array}$ \\
\hline Cook Islands & 2.16 & 1.14 \\
\hline Fiji & 1.09 & 1.06 \\
\hline Kiribati & 0.72 & 0.64 \\
\hline Manus Is (PNG) & 0.74 & 1.53 \\
\hline Marshall Is & 1.23 & 0.40 \\
\hline Nauru & 0.85 & 1.66 \\
\hline Pohnpei (FSM) & 0.72 & 2.20 \\
\hline Samoa & 0.40 & 1.31 \\
\hline Solomon Is & 0.39 & 3.32 \\
\hline Tonga & 3.09 & 0.38 \\
\hline Tuvalu & 0.51 & 1.19 \\
\hline Vanuatu & 1.41 & 0.93 \\
\hline
\end{tabular}

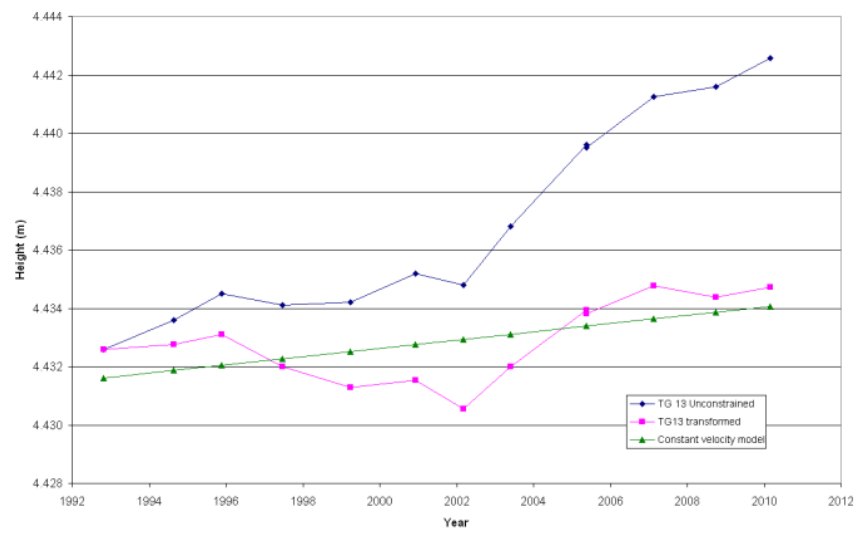

Figure 3: Height variations of the tide gauge in Fiji (FIJ13) using the conventional method holding one height as fixed, the proposed method with inner constraint adjustment, and the conventional results transformed by the velocity difference between the two methods. 


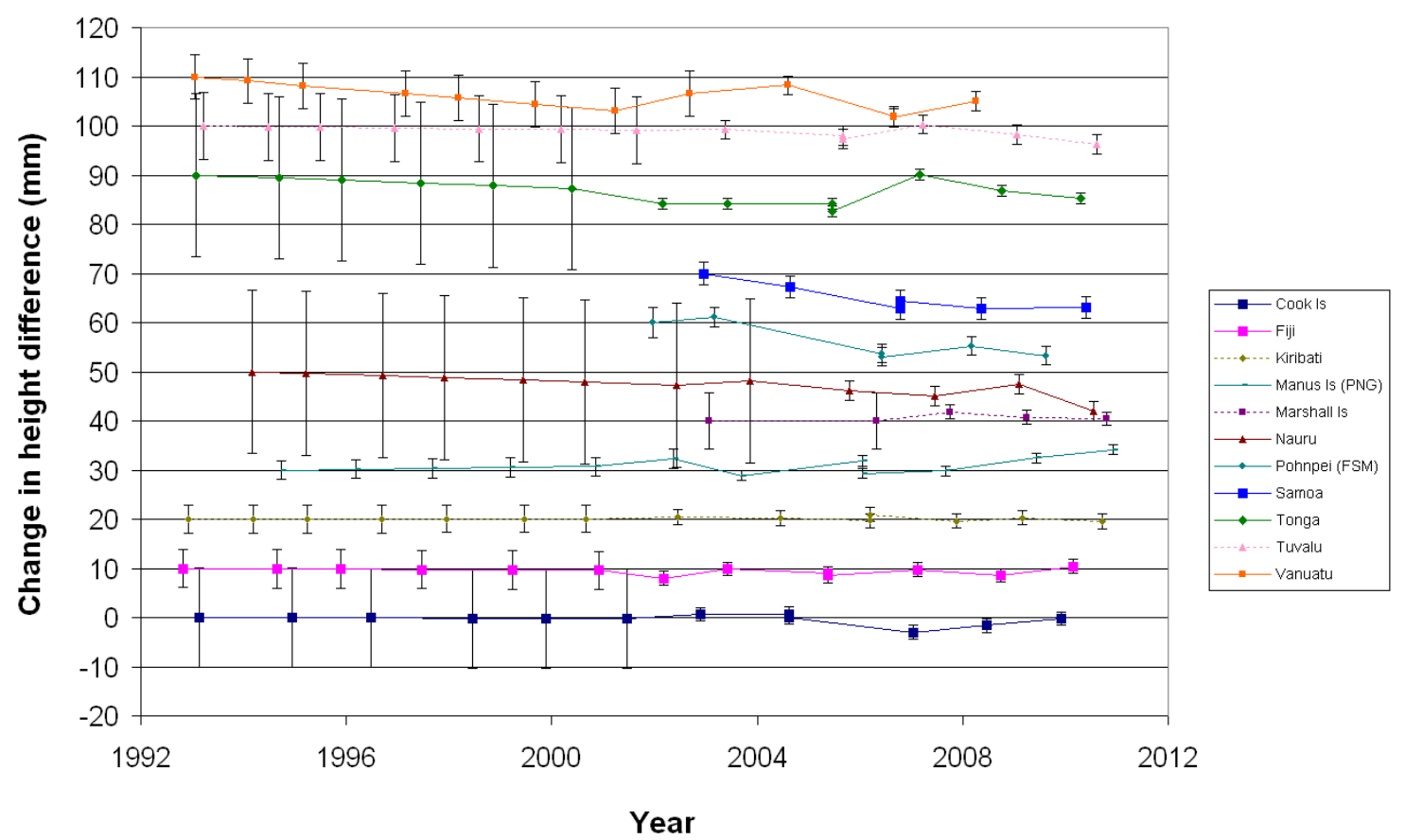

Figure 4: Change on height differences between the CGPS BM and the tide gauge, $H_{T G}-H_{B M}$ at all countries except Solomon Is. A $10 \mathrm{~mm}$ offset has been progressively applied to improve visibility.

The absolute velocities of the CGPS stations in a global and consistent reference frame were obtained by processing GPS data and presenting point coordinates in the ITRF2008 (Altamimi et al., 2011). The velocities were obtained by analysing the time series of station positions since their establishment. The velocities in ITRF2008 are also given in Table 5 for all stations except Solomon Is and Marshall Is, which are relatively new. It is evident that there are significant discrepancies between the ITRF2008 and levelling-determined velocities of the CGPS stations, which indicates deformation in the local region. Also note the high vertical velocity of Tonga and Vanuatu, both of which experience regular earthquakes.

Table 5: Velocity $(\mathrm{mm} / \mathrm{yr})$ of the tide gauges, relative to the CGPS station and the ITRF2008 determined vertical velocities of the CGPS stations. .

\begin{tabular}{|l|l|l|l|l|}
\hline Country & $\begin{array}{l}\text { Tide gauge } \\
\text { velocity } \\
(\mathbf{m m} / \mathbf{y r})\end{array}$ & $\begin{array}{l}\text { CGPS BM } \\
\text { velocity } \\
(\mathbf{m m} / \mathbf{y r})\end{array}$ & $\begin{array}{l}\text { Velocity of tide } \\
\text { gauge wrt CGPS } \\
(\mathbf{m m} / \mathbf{y r})\end{array}$ & $\begin{array}{l}\text { ITRF2008 velocity } \\
\text { of CGPS station } \\
(\mathbf{m m} / \mathbf{y r})\end{array}$ \\
\hline Cook Islands & $0.06 \pm 0.24$ & $0.09 \pm 0.77$ & $-0.03 \pm 0.81$ & $0.6 \pm 0.1$ \\
\hline Fiji & $0.14 \pm 0.13$ & $0.19 \pm 0.28$ & $-0.05 \pm 0.31$ & $0.3 \pm 0.2$ \\
\hline Kiribati & $0.05 \pm 0.20$ & $0.04 \pm 0.18$ & $0.01 \pm 0.27$ & $-0.4 \pm 0.1$ \\
\hline
\end{tabular}




\begin{tabular}{|l|l|l|l|l|}
\hline $\begin{array}{l}\text { Manus Is } \\
\text { (PNG) }\end{array}$ & $-0.08 \pm 0.06$ & $-0.20 \pm 0.15$ & $0.12 \pm 0.16$ & $0.2 \pm 0.2$ \\
\hline $\begin{array}{l}\text { Marshall } \\
\text { Islands }\end{array}$ & $0.02 \pm 0.75$ & $0.01 \pm 0.51$ & $0.01 \pm 0.91$ & N/A \\
\hline Nauru & $0.14 \pm 0.13$ & $0.47 \pm 1.26$ & $-0.33 \pm 1.26$ & $-1.2 \pm 0.2$ \\
\hline $\begin{array}{l}\text { Pohnpei } \\
\text { (FSM) }\end{array}$ & $-0.30 \pm 0.19$ & $0.71 \pm 0.60$ & $-1.01 \pm 0.63$ & $-0.8 \pm 0.2$ \\
\hline Samoa & $-0.72 \pm 0.30$ & $0.22 \pm 0.38$ & $-0.94 \pm 0.49$ & $0.1 \pm 0.2$ \\
\hline Solomon Is & $-0.36 \pm 0.06$ & $-3.48 \pm 0.49$ & $3.12 \pm 0.49$ & $\mathrm{~N} / \mathrm{A}$ \\
\hline Tonga & $-0.38 \pm 0.46$ & $-0.01 \pm 1.21$ & $-0.38 \pm 1.29$ & $2.2 \pm 0.3$ \\
\hline Tuvalu & $-0.11 \pm 0.11$ & $-0.01 \pm 0.49$ & $-0.10 \pm 0.50$ & $0.1 \pm 0.2$ \\
\hline Vanuatu & $-0.44 \pm 0.98$ & $0.40 \pm 0.56$ & $-0.84 \pm 1.13$ & $-3.5 \pm 0.3$ \\
\hline
\end{tabular}

\section{Discussion of Results}

Analysis of results of the CGPS BMs show that the tide gauges are sinking in Pohnpei (FSM), Samoa, Vanuatu, Tonga, Nauru and Tuvalu; rising in Manus Is (PNG); and stable in Fiji, Cook Is and Kiribati. The nett stability between the latter two points is within $1 \mathrm{~mm} /$ year. The results in Solomon Is and Marshall Is are not considered reliable due to the fact that only a few epochs of levelling have been conducted since the recent establishment of the CGPS stations.

\section{Detecting and removing effects of earthquakes and other disturbances}

After obtaining the least squares solution, the RMS of the residuals were calculated, and their values are given in Table 4. Typically, these were better than $1 \mathrm{~mm}$ at the tide gauge and $1.5 \mathrm{~mm}$ at the CGPS BM. Higher values are investigated further. The results for Cook Is showed a $6 \mathrm{~mm}$ residual for point BM18 in 2008, indicating that the point had moved in that epoch. Thus, a height discontinuity was introduced at this point, resulting in a displacement of $-13.9 \mathrm{~mm} \pm 1.4 \mathrm{~mm}$ and an improvement of the overall residual RMS to $0.89 \mathrm{~mm}$. Similar movement was found for BM PNG2 in Papua New Guinea, which moved by $-4.90 \mathrm{~mm} \pm 1.38 \mathrm{~mm}$ in 2008 .

The initial adjustment for Tonga revealed high residuals of up to $10 \mathrm{~mm}$ at the tide gauge, whereas the overall RMS was $1.39 \mathrm{~mm}$. Earlier survey reports stated that BM TON60 had moved by $7 \mathrm{~mm}$ (Geoscience Australia, 2007). Therefore, a height 
discontinuity was introduced which resulted in a displacement of $-6.8 \pm 3.0 \mathrm{~mm}$. Although the overall RMS of the adjustment was improved to $1.05 \mathrm{~mm}$, the high RMS residuals did not improve at the tide gauge.

Vanuatu is regularly struck by strong earthquakes and vertical subsidence as high as $117 \pm 30 \mathrm{~mm}$, which have been recorded for the period 1997 to 2009 , followed by an uplift of $200 \mathrm{~mm}$ after three major earthquakes of 7 October 2009 (Ballu et al., 2011). The Vanuatu tide gauge and nearby BMs were clearly affected by the Earthquake of 2 Jan 2002, as indicated by a large uncertainty in the estimated velocity vector in the initial adjustment. A height discontinuity was introduced at VAN2 on the date of the earthquake and a displacement vector was estimated. After the adjustment, large residuals persisted between the points VAN2-VAN14 and VAN14-VAN16, therefore height discontinuities were also estimated at these points. After applying the displacement vectors to the results, the velocity of the tide gauge continued at the same rate before and after the co-seismic displacement. The total displacement between BMs VAN3 and the tide gauge at VAN16, was estimated as $-34.84 \mathrm{~mm} \pm 6.20 \mathrm{~mm}$. Note that the standard deviation is relatively higher than the accuracy required for sea level determinations. This displacement must be considered when analysing tide gauge data. Although this method removes the effect of co-seismic displacement on BM movements, the uncertainty of the estimates increases with each discontinuity.

\section{Assessment of the Quality of parameters}

The quality of the parameters (the initial heights and velocities of BMs), in terms of their standard deviation, is contained in the variance-covariance matrix after the leastsquares adjustment. Newer BMs were established during the installation of the CGPS stations to satisfy the condition of the use of one BM per kilometre of levelling. The standard deviations of the initial height and velocity estimates of these marks are generally poorer than those of the older ones. In this section, the quality of estimated heights and their velocities of these points are discussed.

In Cook Islands, the GPS BM had standard deviations of $9.84 \mathrm{~mm}$ and 0.77 $\mathrm{mm} / \mathrm{yr}$ in the initial height and velocity estimates, respectively. BM34 and BM35 had high standard deviations in their initial heights, $5.29 \mathrm{~mm}$ and $4.90 \mathrm{~mm}$, and velocity standard deviations of 0.43 and $0.42 \mathrm{~mm} / \mathrm{yr}$, respectively. Though these points had fewer epochs of observations than others, they have been surveyed at least six times since 2001 and their high uncertainties were investigated. The report for the 2002 survey (National Tidal Facility, 2002b) stated that movements of $-3 \mathrm{~mm}$ to $-4 \mathrm{~mm}$ occurred at BMs BM18, BM26, COO10 and COO56, relative to the fundamental BM, BM27. All these points are in a localised area, close to the tide gauge, and it was inferred that a local subsidence had taken place. However, this appears more as an outlier rather than a step when plotting the time series of the height. Thus, it is more likely that a survey error occurred between BM27 to BM18 during the 2002 survey, which accumulated as the survey progressed towards the tide gauge.

Fiji had good overall results with standard deviations in height less than $4 \mathrm{~mm}$ and all velocity standard deviations were less than $0.3 \mathrm{~mm} / \mathrm{yr}$. The standard deviations of points with fewer epochs of observations (BM3246-8 and GPS BM) were slightly higher (3-4 mm; 0.2-0.3 mm/yr) compared to points which have been surveyed since the initial epoch, which on average were with standard deviations $1-2 \mathrm{~mm} ; 0-0.16 \mathrm{~mm} / \mathrm{yr}$. Kiribati had standard deviations better than $2 \mathrm{~mm}$ in height and $0.2 \mathrm{~mm} / \mathrm{yr}$ in velocity. KIR46-49, which have been surveyed for fewer epochs, had slightly higher standard 
deviations (3-4 mm; 0.2-0.3 mm/yr). In PNG, the GPS and BMs PNG29-31, which were installed much later than the initial epoch, had higher standard deviations (1-2 $\mathrm{mm}$; 0.1-0.2 mm/yr) than old marks (0.5-0.7 mm; 0.04-0.15 mm/yr).

In Marshall Is, MAR100 and the GPS BM had height standard deviations of $11.35 \mathrm{~mm}$ and $4.86 \mathrm{~mm}$, with velocity standard deviations of $0.51 \mathrm{~mm} / \mathrm{yr}$ and 1.82 $\mathrm{mm} / \mathrm{yr}$, respectively. Both have been observed for only three epochs since 2007 . MAR107, which has been surveyed only twice, had high standard deviations of 13.28 $\mathrm{mm}$ in height and $1.96 \mathrm{~mm} / \mathrm{yr}$ in velocity. Other BMs had height standard deviations between $3 \mathrm{~mm}$ and $5 \mathrm{~mm}$ and velocity standard deviations between $0.5 \mathrm{~mm} / \mathrm{yr}$ and 1.5 $\mathrm{mm} / \mathrm{yr}$. These exceed the accuracy requirements for accurate sea level monitoring. However, the uncertainties are expected to improve with more surveys in future.

In Nauru, the newer BMs, NAU36-38, had higher standard deviations (2.8-4.2 $\mathrm{mm} ; 0.24-0.35 \mathrm{~mm} / \mathrm{yr}$ ). The CGPS BM had very high standard deviation of $16.72 \mathrm{~mm}$ and $1.26 \mathrm{~mm} / \mathrm{yr}$, whereas other points had low standard deviations (0.7-1.3 mm; 0.1-0.2 $\mathrm{mm} / \mathrm{yr}$ ). It is noted that the survey distance between the CGPS BM and the nearest deep driven bench mark, NAU16, is quite large at $2.15 \mathrm{~km}$. It is likely that survey errors between these points have accumulated and are causing the large uncertainties. Therefore, a deep driven BM between these points is strongly recommended to satisfy the condition of one BM per kilometre.

In FSM (Pohnpei) the standard deviations of heights and their velocities for all points were better than $2 \mathrm{~mm}$ and $0.4 \mathrm{~mm} / \mathrm{yr}$ for all points except for the GPS BM, which were $2.96 \mathrm{~mm}$ and $0.6 \mathrm{~mm} / \mathrm{yr}$. This is likely due to a survey error in the first levelling connection in 2003, which can be verified by comparing results with those from the future surveys The large standard deviation could be also due to accumulation of refraction errors, particularly when the slope of the terrain changes between BM FSM4 $\left(\mathrm{H}\left(\mathrm{t}_{0}\right)=1.7550\right)$ and FSM5 $\left(\mathrm{H}\left(\mathrm{t}_{0}\right)=20.5900\right.$, with a distance of $\left.0.96 \mathrm{~km}\right)$ and between FSM5 and CGPS BM $\left(\mathrm{H}\left(\mathrm{t}_{0}\right)=38.0036\right.$; with a distance $\left.0.88 \mathrm{~km}\right)$. Figure 5 shows high deviations of the height changes from those using the constant velocity model, after transforming to the inner constraint datum at the CGPS BM in Pohnpei (FSM).

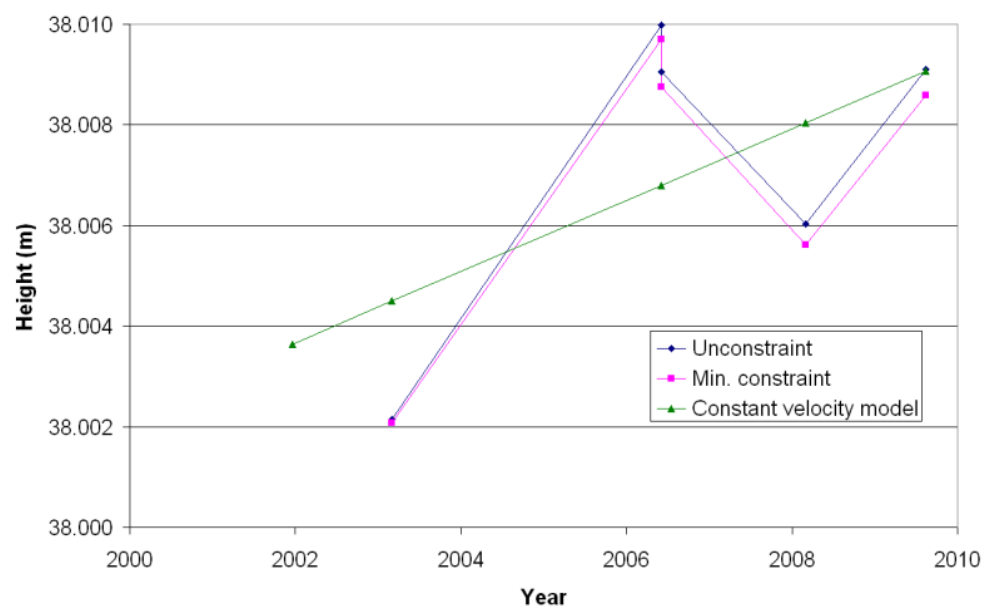

Figure 5: Height variations of the CGPS BM in Pohnpei (FSM) with and without the inner constrain adjustment as well as the height from the constant velocity model.

Samoa had one new BM, BM220, which had high standard deviations (4.68 mm; 0.74 $\mathrm{mm} / \mathrm{yr})$ compared to other points $(0.84-1.41 \mathrm{~mm} ; 0.15-0.38 \mathrm{~mm} / \mathrm{yr})$. The vertical rate of the tide gauge point, $-0.72 \pm 0.3 \mathrm{~mm} / \mathrm{yr}$, is the highest amongst all tide gauges in the 
project. In Solomon Islands, the CGPS BM and new BMs, FBM8-9, which had only three epochs of survey had higher standard deviations $(2-8 \mathrm{~mm} ; 0.2-3.5 \mathrm{~mm} / \mathrm{yr})$ compared to other stations $(0.5-1.2 \mathrm{~mm} ; 0-0.1 \mathrm{~mm} / \mathrm{yr})$. The velocity of the CGPS BM is very high at $-3.48 \pm 0.49 \mathrm{~mm} / \mathrm{yr}$, which requires further investigations using observations from future surveys. There could be an error in one of the surveys which is causing the large velocity changes. Refraction errors could be affecting the results, particularly when the slope of the terrain changes between BM FBM9 $\left(\mathrm{H}\left(\mathrm{t}_{0}\right)=4.74900\right)$ to FBM3 $\left(\mathrm{H}\left(\mathrm{t}_{0}\right)=54.0451\right.$, distance $\left.0.37 \mathrm{~km}\right)$ and FBM3 to CGPS BM $\left(\mathrm{H}\left(\mathrm{t}_{0}\right)=54.3598\right.$; distance $0.31 \mathrm{~km})$.

Tonga had very high standard deviations for the estimated heights of GPS station and new BMs, TON60-62, (4-16 mm; 0.4-1.3 mm/yr) compared to old BMs (3-5 $\mathrm{mm} ; 0.2-0.5 \mathrm{~mm} / \mathrm{yr}$ ). These large standard deviations suggest presence of untreated errors in the data or high disturbance at BMs. In Tuvalu, the GPS station and new BMs, BM25-28, had high standard deviations $(6-19 \mathrm{~mm}$; 0.5-1.15 mm/yr). BM28 had worst results since it has been surveyed only twice, followed by BM25 which was surveyed three times. Other BMs had relatively better results $(0.9-1.1 \mathrm{~mm} ; 0.1 \mathrm{~mm} / \mathrm{yr})$. Vanuatu had results of a good quality (1.7-3.4 mm; 0.2-1 mm/yr). However, the standard deviations of the height and velocity of the tide gauge exceeded the accuracy requirements for accurate sea level monitoring.

\section{Detecting stability of datum benchmarks}

The velocities of the datum BMs relative to each other were considered. BMs which had velocities relatively higher than the other BMs were considered to be unstable. They were detected by outlier analysis based on student t-distribution.

In FSM (Pohnpei), BM FSM3 was removed from the datum points and the adjustment had to be repeated. The datum was sinking at a very high velocity of 1.85 $\mathrm{mm} / \mathrm{yr}$, which caused unreasonably high uplifts in other datum BMs. After removing this station from the datum list and repeating the adjustment the solution changed markedly. The velocity of the tide gauge changed in the opposite direction, from +0.15 to $-0.30 \mathrm{~mm} / \mathrm{yr}$; the GPS BM velocity changed from +1.16 to $+0.71 \mathrm{~mm} / \mathrm{yr}$. The final velocity of FSM3 was very high at $-2.30 \mathrm{~mm} / \mathrm{yr}$.

In Fiji, the velocity of the fundamental BM, BM3243, was $-0.45 \mathrm{~mm} / \mathrm{yr}$ whereas the other datum points, BM3244/5 had velocities of +0.20 and $+0.25 \mathrm{~mm} / \mathrm{yr}$, respectively. This implies that the fundamental BM is sinking at a considerably higher rate compared to the other points. Similar case is encountered for BM26 in Cook Is. Both these marks are in coastal areas in reclaimed land, which could explain their high velocities. However, their removal would result in only two datum points, which is not acceptable, as results would be unreliable since it would be difficult to detect relative movement in case one of the points becomes unstable. A preferred approach for the future would be to bring the initial epoch forward in order to use more of the newer deep driven BMs as datum points.

The datum BMs in Kiribati, Manus Is (PNG), Nauru, Solomon Is, Tonga and Tuvalu were relatively stable with the sum of their velocities less than $0.1 \mathrm{~mm} / \mathrm{yr}$. In Samoa, all datum points had low relative velocities. However, BM201 and BM210, which are closer to the coast, had slightly higher velocities at $0.4 \mathrm{~mm} / \mathrm{yr}$, compared to the inlands BMs, which had velocities less than $0.2 \mathrm{~mm} / \mathrm{yr}$. The Vanuatu datum points VAN3 and VAN100 had velocities of -0.17 and $-0.18 \mathrm{~mm} / \mathrm{yr}$, whereas VAN101 had a 
velocity of $+0.35 \mathrm{~mm} / \mathrm{yr}$. Even tough the nett velocity amongst these three stations is zero; there was a considerable relative motion amongst them.

In the initial adjustment for Marshall Islands, MAR15 had a high vertical velocity at $-1.13 \mathrm{~mm} / \mathrm{yr}$ compared to the lower velocity of $-0.38 \mathrm{~mm} / \mathrm{yr}$ for MAR3 and the other datum point. This caused an unrealistically high velocity of $-1.01 \mathrm{~mm} / \mathrm{yr}$ of the tide gauge. Thus, MAR15 had to be removed from the datum list and the initial epoch was brought forward to 2003. This allowed the inclusion of BMs MAR51-52 to the datums list and the estimated velocity of the tide gauge was reduced to almost zero. This shows that the tide gauge is relatively stable in relation to the land mass.

\section{Comparison with ITRF2008 solutions}

Table 5 shows large discrepancies in the vertical velocity of the CGPS stations from the levelling and the ITRF2008 determined solutions, with an average value of $0.4 \mathrm{~mm} / \mathrm{yr}$. The ITRF2008 solutions are in a globally consistent reference frame whereas the levelling velocities are relative to a group of datum BMs in the local area. The high differences are due to deformations in the local area, relative to the global reference frame, as well as errors in levelling.

Examining the time series of the ITRF2008 residuals for each station revealed that there were several gaps in the time series solutions for the CGPS stations. This may be due to delays in providing the GPS data from the SPSLCMP network to the International GNSS Service (IGS) analysis centres in time for processing. Annual and semi-annual seasonal signals were visible in the time series, particularly in the height component, which is typical in GPS time series (Amiri-Simkooei et al., 2007; Teferle et al., 2007; El-Mowafy, 2009). These are likely to be due to residual ocean or atmospheric loading effects, which are not accurately accounted for in the GNSS processing (Altamimi and Collilieux, 2009).

It is possible to apply the difference in the velocities between the levelling and ITRF2008 solutions as a correction for the local deformation with respect to the global frame. However, the RMS of the transformed heights with respect to the constant velocity modelled heights is quite high for some stations, as shown in Table 4. This shows that the motion of the GPS BM is non-linear and possibly affected by geophysical effects, which cannot be measured by levelling since the 1.5 year interval in-between surveys is too long compared to the frequency of geophysical effects. Similar problems were encountered in Tervo et al. (2006). Therefore, it is highly recommended to implement more continuous monitoring of the tide gauge stability. One possibility is the dual-CGPS concept (Teferle et al., 2002), where a CGPS station is established at the tide gauge, while another station is located on stable rock within a few kilometres of the tide gauge. By analysing the time series of the two co-located stations, spatial correlations can be removed by differencing their positions to obtain a cleaner time series of vertical land motion. This is especially required wherever the tide gauges are in a disturbed area, or if their area experience frequent earthquakes and significant geophysical signals.

\section{Conclusions}

The vertical velocities of the tide gauges have been calculated successfully in a group of South Pacific Countries with their respective uncertainties estimated from the repeated levelling and EDM trigonometric height traversing. The approach was based on an inner 
constraint adjustment which assumed constant velocities for modelling the vertical motion of the used BMs. Stability of individual deep BMs was also confirmed. It was shown that significant relative movements exist between the CGPS stations and the tide gauge point, which were not necessarily linear. The tide gauges were found to be sinking relative to the CGPS BMs in Pohnpei (FSM), Samoa, Vanuatu, Tonga, Nauru and Tuvalu. They were rising in Manus Is (PNG) and Solomon Is; and relatively stable at Fiji, Cook Is, Marshall Is and Kiribati. For Marshall Is and Solomon Is, these velocities must be treated with caution due to the recent establishment of the CGPS stations. The best results for the nett velocities of the tide gauges, in order of their best performance were Kiribati, Manus Is (PNG), Fiji, Samoa, and Tuvalu. Of these, the uncertainties for Kiribati and Manus Is (PNG) matched the uncertainty of the recently determined sea level rise estimates.

The velocity of the tide gauge in Tonga was affected by a possible collusion of the tide gauge with a ship whereas the Cook Is BMs were likely to be affected by errors in the 2002 survey. The effects of earthquakes and localised disturbances were removed in Vanuatu, Manus Is (PNG) and Cook Is. The nett velocity in Vanuatu had a high uncertainty of $1.13 \mathrm{~mm} / \mathrm{year}$, which was due to introducing height displacements at 3 BMs.

In terms of how well the constant velocity model fits the observations at the tide gauges, large deviations were found in Tonga and Cook Is due to local deformations and survey errors. This model is not appropriate for tide gauges at Fiji, Marshall Is and Vanuatu, as there seems to be some variability in their motion. As for the GPS BMs, large deviations of few millimetres, were present in all cases. This is probably due to high frequency geophysical effects at the CGPS BM which cannot be measured by the levelling method since they occur more frequently than the 1.5 years between surveys.

Continuously measuring the tide gauge movements through implementing the dual-CGPS concept would greatly enhance the quality of monitoring the tide gauge stability, especially where they are disturbed by earthquakes and geophysical signals, e.g. at Vanuatu, Cook Islands. This will allow the determination of the exact date of disturbances to the tide gauges, which can be applied to the sea level data related to the tide gauge.

\section{Acknowledgements}

The second author publishes with the permission of the Chief Executive Officer, Geoscience Australia (GA). The comments and suggestions by Dr John Dawson are most valued. This study made use of levelling data collected collaboratively by staff of GA, National Tidal Facility, Australia (NTF) and Secretariat of the Pacific Community (SOPAC) with funding from AusAID. The authors thank the survey team including Steven Turner, Brian Ratcliff, Bob Twilley, Steve Yates, Andrick Lal, Nick Brown and Guorong Hu.

\section{References}

Altamimi, Z., Collilieux, X. 2009. IGS contribution to the ITRF. Journal of Geodesy. 83 (3-4): 375-383.

Altamimi, Z., Collilieux, X., Metivier, L. 2011. ITRF2008: an improved solution of the international terrestrial reference frame. Journal of Geodesy, doi:10.1007/s00190011-0444-4. 
Amiri-Simkooei, A.R., Tiberius, C.C.J.M., Teunissen, P.J.G. 2007. Assessment of noise in GPS coordinate time series: Methodology and results, J. Geophys. Res. 112, doi:10.1029/2006JB004913.

Anastasio, E.D., De Martini, P.M., Selvaggi, G., Pantosti, D., Marchioni, A., Maseroli, R. 2006. Short-term vertical velocity field in the Apennines (Italy) revealed by geodetic levelling data. Tectonophysics. 418: 219-234.

Ballu, V.B., Bouin, M.N., Simeoni, P., Crawford, W.C., Calmant, S., Bore, J.M., Kanas, T., Pelletier, B. 2011. Comparing the role of absolute sea-level rise and vertical tectonic motions in coastal flooding, Torres Islands (Vanuatu). Proceeding of the National Academy of Sciences: Environmental Sciences - Geophysics. 108 (32): 13019-13022.

Blewitt, G., Altamimi, Z., Davis, J., Gross, R., Kuo, C., Lemoine, F., Neilan, R., Plag, H.P., Rothacher, M., Shum, C.K., Sideris, M.G., Schöne, T., Tregoning, P., Zerbini, S. 2006. Geodetic observations and global reference frame contributions to understanding sea level rise and variability, in: Proc. WCRP Workshop Understanding Sea-Level Rise and Variability, UNESCO, Paris, 6-9 June 2006, pp. $145-170$.

Bureau of Meteorology. 2007. South Pacific Sea Level and Climate Monitoring Project, Australian Bureau of Meteorology, viewed 31 January 2011, <http://www.bom.gov.au/pacificsealevel/>.

Ceylan, A. and Baykal, O. 2006. Precise Height Determination Using Leap-Frog Trigonometric Leveling. Journal of Surveying Engineering. 132 (3): 118-123.

Church, J.A. and White, J.W. 2011. Sea-Level Rise from the Late 19th to the Early 21st Century. Surveys in Geophysics. doi:10.1007/s10712-011-9119-1.

Donnelly, N. 2012. Determining Coordinates in a Local Reference Frame from Absolute ITRF Positions: A New Zealand Case Study, IAG/FIG Technical Seminar, Reference Frame in Practice, Rome, Italy, 4-5 May, 2012.

Douglas, B.C. 1997. Global sea rise: A redetermination. Surv. Geophys. 18: 279-292.

El-Mowafy, A. (2009) "An Alternative Post-Processing Relative Positioning Approach Based on Precise Point Positioning", Journal of Surveying Engineering, ASCE, 135(2): 56-65.

Geoscience Australia. 2007. Survey Report: EDM height traversing levelling survey, Tonga. Geoscience Australia, Canberra, March 2007.

Holdahl, S.R. 1979. Removal of refraction errors in geodetic levelling, in: Tengstrom, E., Teleki, G., (Eds.), Refractional Influences in Astronomy and Geodesy. International Astronomical Union: 305-319.

Kharaghani, G.A. 1987. Propagation of refraction errors in trigonometric height traversing and geodetic levelling. Technical Report No 132, Department of Surveying Engineering, University of New Brunswick.

Kimata, F., Miyajima, R., Murase, M., Darwaman, D., Ito, T., Ohata, Y., Irwan, M., Takano, K., Ibrahim, F., Koyama, E., Tsuji, H., Takayama, T., Uchida, K., Okada, J., Solim, D., Anderson, H., 2004. Ground uplift detected by precise levelling in the Ontake earthquake swarm area, central Japan in 2002-2004. Earth Planets Space. 56: 45-48.

Leal, J. 1989. Integration of GPS and levelling for subsidence monitoring studies at Costa Bolivar oil fields. Venezuela. Technical Report No. 144, University of New Brunswick. 
Lenotre, N., Thierry, P., Blanchin, R., Brochard, G. 1999. Current vertical movement demonstrated by comparative levelling in Brittany (northwestern France). Tectonophysics 301: 333-344.

Makinen, J. and Saaranen, V. 1998. Determination of post-glacial land uplift from the three precise levellings in Finland. J. Geodesy. 72: 516-529.

Makinen, J., Koivula, H., Poutanen, M., Saarnen, V. 2003. Vertical velocities in Finland from permanent GPS networks and from repeated precise levelling. J. Geodynamics. 38: 443-456.

Murray, J.B., Wooller, L.K. 2002. Persistent summit subsidence at Volcan de Colima, Mexico, 1982-1999: strong evidence against Mogi deflation. J. Volcanology and Geothermal Research. 117 (1-2): 69-78.

National Tidal Facility. 2002a. Survey Report: Precise Differential Levelling Vanuatu. National Tidal Facility, Australia, September 2002.

National Tidal Facility. 2002b. Survey Report: Precise Differential Levelling Cook Islands. National Tidal Facility, Australia, December 2002.

Rueger, J.M., Brunner, F.K. 1981. Practical results of EDM-height traversing. The Australian Surveyor. 30 (6): 363-372.

Schlatter, A., Schneider, D., Gieger, A., Kahle, H.G. 2005. Recent vertical movements from precise levelling in the vicinity of the city of Basel, Switzerland. Int. J. Earth Sci. (Geol Rundsch). 94: 507-514.

Teferle, F.N., Bingley, R.M., Dodson, A.H., Baker, T.F. 2002. Application of the dualCGPS concept to monitoring vertical land movements at tide gauges, Physics and Chemistry of the Earth, Parts A/B/C, Vol 27, (32-34):. 1401-1406.

Teferle, F.N., Williams, S.D.P., Kierulf, H.P., Bingley, R.M., Plag, H.P. 2008. A continuous GPS coordinate time series analysis strategy for high-accuracy vertical land movements, Physics and Chemistry of the Earth, Parts A/B/C, Vol 33 (3-4): 194-204.

Tervo, M., Poutanen, M., Koivula, H. 2006. Tide gauge monitoring using GPS, In: Dynamic Planet-Monitoring and Understanding a Dynamic Planet with Geodetic and Oceanographic Tools, Conference of the International Association of Geodesy 22-26 August 2005, Cairns, Australia (Rizos, C. and Tregoning, P.(eds.), International Association of Geodesy Symposia, Springer Verlag, Vol. 130: 7579.

Tushingham, A.M. and Peltier, W.R. 1991. Ice-3G: A new global model of late Pleistocene deglaciation based upon predictions of post-glacial relative sea level change. J. Geophys. Res. 96: 4497-4523.

Verdonck, V. 2006. Contemporary vertical crustal deformation in Cascadia. Tectonophysics. 417 (3-4): 221-230.

\section{Appendix A}

Table 6 gives Comparison of offsets between the CGPS BM and the tide gauge obtained by direct measurements and from the inner constraint adjustment. The standard deviations $(\sigma)$ for the measured offsets are based on first order levelling standards whereas for the adjusted offsets, they are derived from the least squared adjustment.

Table 6: Comparison of offsets between the CGPS BM and the tide gauge obtained by direct measurements and from the inner constraint adjustment. 


\begin{tabular}{|c|c|c|c|c|c|c|c|}
\hline $\begin{array}{l}\text { Country/ } \\
\text { RMS } \\
(\mathrm{mm})\end{array}$ & $\begin{array}{l}\text { Epoch } \\
\text { (yr) }\end{array}$ & $\begin{array}{l}\text { Measured } \\
\text { Offset } \\
\text { and } \sigma(\mathrm{m})\end{array}$ & $\begin{array}{l}\text { Adjusted } \\
\text { Offset } \\
\text { and } \sigma \\
\text { (m) }\end{array}$ & $\begin{array}{l}\text { Country/ } \\
\text { RMS } \\
(\mathrm{mm})\end{array}$ & $\begin{array}{l}\text { Epoch } \\
\text { (yr) }\end{array}$ & $\begin{array}{l}\text { Measured } \\
\text { Offset } \\
\text { and } \sigma(\mathrm{m})\end{array}$ & $\begin{array}{l}\text { Adjusted } \\
\text { Offset } \\
\text { and } \sigma \\
\text { (m) }\end{array}$ \\
\hline \multirow[t]{6}{*}{$\begin{array}{l}\text { Cook Is / } \\
1.3 .\end{array}$} & 2002.9 & $\begin{array}{l}-0.5693 \pm \\
0.0014\end{array}$ & $\begin{array}{l}-0.5702 \\
\pm 0.0101\end{array}$ & $\begin{array}{l}\text { Pohnpei } \\
(\mathrm{FSM}) / \\
1.9\end{array}$ & 2003.2 & $\begin{array}{l}-33.9696 \\
\pm 0.0019\end{array}$ & $\begin{array}{r}-33.9719 \\
\pm 0.0030\end{array}$ \\
\hline & 2004.6 & $\begin{array}{l}-0.5692 \pm \\
0.0014\end{array}$ & $\begin{array}{l}-0.5703 \\
\pm 0.0101\end{array}$ & & 2006.4 & $\begin{array}{l}-33.9770 \\
\pm 0.0019\end{array}$ & $\begin{array}{l}-33.9752 \\
\pm 0.0030\end{array}$ \\
\hline & 2004.6 & $\begin{array}{l}-0.5698 \pm \\
0.0014\end{array}$ & $\begin{array}{l}-0.5703 \\
\pm 0.0101\end{array}$ & & 2006.4 & $\begin{array}{r}-33.9776 \\
\pm 0.0019\end{array}$ & $\begin{array}{r}-33.9752 \\
\pm 0.0030\end{array}$ \\
\hline & 2007.0 & $\begin{array}{l}-0.5729 \pm \\
0.0014\end{array}$ & $\begin{array}{l}-0.5704 \\
\pm 0.0101\end{array}$ & & 2008.2 & $\begin{array}{r}-33.9755 \\
\pm 0.0019\end{array}$ & $\begin{array}{r}-33.9769 \\
\pm 0.0030\end{array}$ \\
\hline & 2008.5 & $\begin{array}{l}-0.5715 \pm \\
0.0014\end{array}$ & $\begin{array}{l}-0.5704 \\
\pm 0.0101\end{array}$ & & 2009.6 & $\begin{array}{r}-33.9775 \\
\pm 0.0019\end{array}$ & $\begin{array}{r}-33.9784 \\
\pm 0.0030\end{array}$ \\
\hline & 2009.9 & $\begin{array}{l}-0.5702 \pm \\
0.0014\end{array}$ & $\begin{array}{l}-0.5705 \\
\pm 0.0101\end{array}$ & $\begin{array}{l}\text { Samoa/ } \\
1.3\end{array}$ & 2003.0 & $\begin{array}{r}-34.0235 \\
\pm 0.0022\end{array}$ & $\begin{array}{r}-34.0248 \\
\pm 0.0017\end{array}$ \\
\hline \multirow[t]{4}{*}{ Fiji/ 0.9} & 2002.2 & $\begin{array}{r}-26.8989 \\
\pm 0.0014\end{array}$ & $\begin{array}{r}-26.8973 \\
\pm 0.0039\end{array}$ & & 2004.6 & $\begin{array}{r}-34.0262 \\
\pm 0.0022\end{array}$ & $\begin{array}{l}-34.0264 \\
\pm 0.0017\end{array}$ \\
\hline & 2003.4 & $\begin{array}{l}-26.8970 \\
\pm 0.0014\end{array}$ & $\begin{array}{r}-26.8974 \\
\pm 0.0039\end{array}$ & & 2006.8 & $\begin{array}{l}-34.0306 \\
\pm 0.0022\end{array}$ & $\begin{array}{l}-34.0284 \\
\pm 0.0017\end{array}$ \\
\hline & 2005.4 & $\begin{array}{l}-26.8979 \\
\pm 0.0014\end{array}$ & $\begin{array}{r}-26.8975 \\
\pm 0.0039\end{array}$ & & 2006.8 & $\begin{array}{r}-34.0292 \\
\pm 0.0022\end{array}$ & $\begin{array}{r}-34.0284 \\
\pm 0.0017\end{array}$ \\
\hline & 2005.4 & -26.8984 & -26.8975 & & 2008.4 & -34.0306 & -34.0298 \\
\hline
\end{tabular}




\begin{tabular}{|c|c|c|c|c|c|c|c|}
\hline & & \pm 0.0014 & \pm 0.0039 & & & \pm 0.0022 & \pm 0.0017 \\
\hline & 2007.1 & $\begin{array}{r}-26.8972 \\
\pm 0.0014\end{array}$ & $\begin{array}{r}-26.8976 \\
\pm 0.0039\end{array}$ & & 2010.4 & $\begin{array}{r}-34.0304 \\
\pm 0.0022\end{array}$ & $\begin{array}{l}-34.0317 \\
\pm 0.0017\end{array}$ \\
\hline & 2008.7 & $\begin{array}{r}-26.8983 \\
\pm 0.0014\end{array}$ & $\begin{array}{r}-26.8977 \\
\pm 0.0039\end{array}$ & $\begin{array}{l}\text { Solomon } \\
\text { Is / } 3.2\end{array}$ & 2007.7 & $\begin{array}{l}-50.7391 \\
\pm 0.0011\end{array}$ & $\begin{array}{r}-50.7436 \\
\pm 0.0073\end{array}$ \\
\hline & 2010.2 & $\begin{array}{l}-26.8965 \\
\pm 0.0014\end{array}$ & $\begin{array}{r}-26.8977 \\
\pm 0.0039\end{array}$ & & 2009.4 & $\begin{array}{r}-50.7415 \\
\pm 0.0011\end{array}$ & $\begin{array}{r}-50.7384 \\
\pm 0.0073\end{array}$ \\
\hline $\begin{array}{l}\text { Kiribati / } \\
0.5\end{array}$ & 2002.4 & $\begin{array}{l}0.2197 \pm \\
0.0015\end{array}$ & $\begin{array}{l}0.2193 \pm \\
0.0028\end{array}$ & & 2010.9 & $\begin{array}{l}-50.7325 \\
\pm 0.0011\end{array}$ & $\begin{array}{l}-50.7336 \\
\pm 0.0073\end{array}$ \\
\hline & 2004.4 & $\begin{array}{l}0.2194 \pm \\
0.0015\end{array}$ & $\begin{array}{l}0.2193 \pm \\
0.0028\end{array}$ & $\begin{array}{l}\text { Tonga / } \\
2.9\end{array}$ & 2002.2 & $\begin{array}{l}1.9070 \pm \\
0.0011\end{array}$ & $\begin{array}{l}1.9094 \pm \\
0.0165\end{array}$ \\
\hline & 2006.2 & $\begin{array}{l}0.2189 \pm \\
0.0015\end{array}$ & $\begin{array}{l}0.2194 \pm \\
0.0028\end{array}$ & & 2003.4 & $\begin{array}{l}1.9069 \pm \\
0.0011\end{array}$ & $\begin{array}{l}1.9089 \pm \\
0.0165\end{array}$ \\
\hline & 2006.2 & $\begin{array}{l}0.2202 \pm \\
0.0015\end{array}$ & $\begin{array}{l}0.2194 \pm \\
0.0028\end{array}$ & & 2005.5 & $\begin{array}{l}1.9070 \pm \\
0.0011\end{array}$ & $\begin{array}{l}1.9081 \pm \\
0.0165\end{array}$ \\
\hline & 2007.9 & $\begin{array}{l}0.2189 \pm \\
0.0015\end{array}$ & $\begin{array}{l}0.2194 \pm \\
0.0028\end{array}$ & & 2005.5 & $\begin{array}{l}1.9054 \pm \\
0.0011\end{array}$ & $\begin{array}{l}1.9081 \pm \\
0.0165\end{array}$ \\
\hline & 2009.2 & $\begin{array}{l}0.2195 \pm \\
0.0015\end{array}$ & $\begin{array}{l}0.2194 \pm \\
0.0028\end{array}$ & & 2007.2 & $\begin{array}{l}1.9128 \pm \\
0.0011\end{array}$ & $\begin{array}{l}1.9075 \pm \\
0.0165\end{array}$ \\
\hline & 2010.7 & $\begin{array}{l}0.2188 \pm \\
0.0015\end{array}$ & $\begin{array}{l}0.2194 \pm \\
0.0028\end{array}$ & & 2008.8 & $\begin{array}{l}1.9097 \pm \\
0.0011\end{array}$ & $\begin{array}{l}1.9069 \pm \\
0.0165\end{array}$ \\
\hline $\begin{array}{l}\text { Manus Is } \\
\text { (PNG)/ } \\
1.7\end{array}$ & 2002.4 & $\begin{array}{l}-33.1068 \\
\pm 0.0010\end{array}$ & $\begin{array}{r}-33.1082 \\
\pm 0.0019\end{array}$ & & 2010.3 & $\begin{array}{l}1.9080 \pm \\
0.0011\end{array}$ & $\begin{array}{l}1.9063 \pm \\
0.0165\end{array}$ \\
\hline
\end{tabular}




\begin{tabular}{|c|c|c|c|c|c|c|c|}
\hline & 2003.7 & $\begin{array}{l}-33.1102 \\
\pm 0.0010\end{array}$ & $\begin{array}{r}-33.1080 \\
\pm 0.0019\end{array}$ & $\begin{array}{l}\text { Tuvalu/ } \\
1.2\end{array}$ & 2003.4 & $\begin{array}{l}1.7179 \pm \\
0.0019\end{array}$ & $\begin{array}{l}1.7176 \pm \\
0.0068\end{array}$ \\
\hline & 2006.0 & $\begin{array}{l}-33.1072 \\
\pm 0.0010\end{array}$ & $\begin{array}{r}-33.1078 \\
\pm 0.0019\end{array}$ & & 2005.7 & $\begin{array}{l}1.7168 \pm \\
0.0019\end{array}$ & $\begin{array}{l}1.7174 \pm \\
0.0068\end{array}$ \\
\hline & 2006.0 & $\begin{array}{l}-33.1098 \\
\pm 0.0010\end{array}$ & $\begin{array}{r}-33.1078 \\
\pm 0.0019\end{array}$ & & 2005.7 & $\begin{array}{l}1.7160 \pm \\
0.0019\end{array}$ & $\begin{array}{l}1.7174 \pm \\
0.0068\end{array}$ \\
\hline & 2007.7 & $\begin{array}{l}-33.1092 \\
\pm 0.0010\end{array}$ & $\begin{array}{r}-33.1076 \\
\pm 0.0019\end{array}$ & & 2007.2 & $\begin{array}{l}1.7190 \pm \\
0.0019\end{array}$ & $\begin{array}{l}1.7172 \pm \\
0.0068\end{array}$ \\
\hline & 2009.4 & $\begin{array}{l}-33.1067 \\
\pm 0.0010\end{array}$ & $\begin{array}{l}-33.1074 \\
\pm 0.0019\end{array}$ & & 2009.1 & $\begin{array}{l}1.7170 \pm \\
0.0019\end{array}$ & $\begin{array}{l}1.7171 \pm \\
0.0068\end{array}$ \\
\hline & 2010.9 & $\begin{array}{l}-33.1050 \\
\pm 0.0010\end{array}$ & $\begin{array}{l}-33.1072 \\
\pm 0.0019\end{array}$ & & 2010.6 & $\begin{array}{l}1.7150 \pm \\
0.0019\end{array}$ & $\begin{array}{l}1.7169 \pm \\
0.0068\end{array}$ \\
\hline $\begin{array}{l}\text { Marshall } \\
\text { Is/ } 1.1\end{array}$ & 2007.75 & $\begin{array}{l}-0.3481 \pm \\
0.0014\end{array}$ & $\begin{array}{l}-0.3498 \\
\pm 0.0058\end{array}$ & $\begin{array}{l}\text { Vanuatu/ } \\
5.8\end{array}$ & 2002.7 & $\begin{array}{l}-27.9001 \\
\pm 0.0019\end{array}$ & $\begin{array}{r}-27.9047 \\
\pm 0.0046\end{array}$ \\
\hline & 2009.25 & $\begin{array}{l}-0.3492 \pm \\
0.0014\end{array}$ & $\begin{array}{l}-0.3498 \\
\pm 0.0058\end{array}$ & & 2004.6 & $\begin{array}{r}-27.8984 \\
\pm 0.0019\end{array}$ & $\begin{array}{r}-27.9063 \\
\pm 0.0046\end{array}$ \\
\hline & 2010.81 & $\begin{array}{l}-0.3494 \pm \\
0.0014\end{array}$ & $\begin{array}{l}-0.3498 \\
\pm 0.0058\end{array}$ & & 2006.7 & $\begin{array}{r}-27.9047 \\
\pm 0.0019\end{array}$ & $\begin{array}{r}-27.9081 \\
\pm 0.0046\end{array}$ \\
\hline $\begin{array}{l}\text { Nauru / } \\
1.7\end{array}$ & 2003.9 & $\begin{array}{l}0.7476 \pm \\
0.0020\end{array}$ & $\begin{array}{l}0.7463 \pm \\
0.0167\end{array}$ & & 2006.7 & $\begin{array}{r}-27.9050 \\
\pm 0.0019\end{array}$ & $\begin{array}{l}-27.9081 \\
\pm 0.0046\end{array}$ \\
\hline & 2005.8 & $\begin{array}{l}0.7457 \pm \\
0.0020\end{array}$ & $\begin{array}{l}0.7457 \pm \\
0.0167\end{array}$ & & 2008.3 & $\begin{array}{r}-27.9016 \\
\pm 0.0019\end{array}$ & -27.9094 \\
\hline & 2007.5 & $0.7445 \pm$ & $0.7451 \pm$ & & & & \\
\hline
\end{tabular}




\begin{tabular}{|l|l|l|l|l|l|l|l|}
\hline & & 0.0020 & 0.0167 & & & & \\
\hline & 2009.1 & $0.7469 \pm$ & $0.7446 \pm$ & & & & \\
& & 0.0020 & 0.0167 & & & & \\
\hline & 2010.5 & $0.7414 \pm$ & $0.7441 \pm$ & & & & \\
& & 0.0020 & 0.0167 & & & & \\
\hline
\end{tabular}

